\title{
Dynamics, Hydrological Relations and Pollution of Precipitation and Flood Waters in a Forest Ecosystem
}

\author{
Damir Ugarkovići ${ }^{*}$, Danijela Balta², Ivica Tikvići ${ }^{1}$ Marko Vucelja ${ }^{3}$, Igor Stankić ${ }^{4}$
}

(1) University of Zagreb, Faculty of Forestry, Department of Forest Ecology and Silviculture, Svetošimunska 25, HR-10002 Zagreb, Croatia; (2) Paštanska 8, HR-32256 Strošinci, Croatia; (3) University of Zagreb, Faculty of Forestry, Department of Forest Protection and Wildlife Management, Svetošimunska 25, HR-10002 Zagreb, Croatia; (4) Energy and Environmental Protection Institute (EKONERG), Koranska 5, HR-10000 Zagreb, Croatia

* Correspondence: e-mail: damir.ugarkovic@gs.htnet.hr
Citation: UGARKOVIĆ D, BALTA D, TIKVIĆ I, VUCELJA M, STANKIĆ I 2017 Dynamics, Hydrological Relations and Pollution of Precipitation and Flood Waters in a Forest Ecosystem. South-east Eur for 8 (1): 51-58. DOI: https://doi.org/10.15177/ seefor.17-07

Received: 23 Feb 2017; Revised: 29 Apr 2017; Accepted: 3 May 2017; Published online: 24 May 2017

\begin{abstract}
Background and Purpose: Water in forest ecosystems can be present in various forms. The hydrological water cycle unfolds via fundamental hydrological processes such as evapotranspiration, precipitation, infiltration and outflow. Certain infrastructure works and recent climate changes within lowland forest areas have resulted in changes in flood water and ground water trends, and in quantities of precipitation and evapotranspiration. One of the chemical water quality indicators is the presence of metals in water. Higher metal concentrations in natural waters are undesirable since they are polluters of aquatic systems and detrimental to living organisms. Particularly dangerous are cadmium and lead. The objective of this paper was to analyse watercourse levels, ground water depths, and relations between precipitation waters, flood waters, ground waters, relative air humidity and evapotranspiration. An additional objective was to analyse the pollution of precipitation and flood waters in lowland forest ecosystems.

Materials and Methods: The study was conducted in the Posavina region in Croatia. Precipitation data from Nova Gradiška meteorological station, watercourse levels of the Sava River and ground water depth data from piezometer stations were used in the analysis of the hydrological relations. For water quality analysis, precipitation was collected at six sample sites during the spring of 2015 and 2016. Flood water and precipitation were collected in three repetitions during the spring of 2015 and 2016.

Results: Trends of the Sava River water levels and ground water levels dropped significantly. The precipitation volume trend in the study area was positive, but not statistically significant, while evapotranspiration amounts increased significantly. Conclusions: A significant correlation has been found between particular water forms in the hydrological cycle, i.e. between precipitation waters, flood waters and ground waters, and between relative air humidity and evapotranspiration. No pollution of precipitation waters and flood waters with metals was found.
\end{abstract}

Keywords: hydrological cycle, forest ecosystem, water pollution

\section{INTRODUCTION}

As an ecological factor in an ecosystem, water can be present in the form of precipitation, flood water, ground water or air moisture. Precipitation water usually comes in the form of rain or snow, and is a result of water vapour condensation in the atmosphere. Other forms of precipitations, such as fog, dew and frost, can also be conditionally added to the total sum of precipitation. Precipitations are an important part of the water cycle and a primary source for ground water charging [1]. Flood water is necessary for normal functioning of lowland forest ecosystems. Floods of the Sava River and its tributaries have a specific rhythm. Maximal water levels of the Sava are achieved in March, April, October, November and December, when floods can be expected in lowland forests [2]. Ground water depth directly depends on the water level in rivers [3], while it indirectly depends on precipitation and flood waters. Part of precipitation that seeps into soil is used to moisten it, while the remainder runs off to parent soil, moistens it and on impermeable layers forms the aquifer 
[4]. Air humidity as a factor has less of an effect on forest ecosystems and their formation, but is very important for cells, tissues and other plant organs that are saturated with water vapour. Temperature affects the capacity of air to hold water vapour. The higher the temperature, the greater the capacity for water vapour and air humidity, and the lesser the transpiration. Many studies have reported changes in hydrological relations, particularly changes in the dynamics of ground water [5-7]. Flood intensities also change and vary from year to year, in the range from minimum to maximum water, and as such are an important ecological factor.

Water constantly cycles in nature and this circulation is called the hydrological cycle [8]. The hydrological cycle unfolds in the atmosphere, hydrosphere (surface) and in the lithosphere. All plants, along with the rest of the living world, are part of the water cycle, thus changing form, but never disappearing. This cycle is controlled by the Sun's energy and by gravity. The hydrological cycle has five processes: condensation, precipitation, infiltration, runoff and evapotranspiration [9]. In the hydrological cycle, water changes are the fastest in the atmosphere and biosphere [10]. Few studies have examined the relationship between specific water forms and climate indices in the hydrological cycle of lowland forests. Direct relationship between the Drava River water level and ground water depths in the Repeš forest was reported by [3]. The present study examines a range of different water forms and climate indices, in order to obtain data on interrelationships in the hydrological cycle of lowland forests. It can be expected that changes in global climate will have effect on the hydrological cycle, and that they will change the level of surface water and ground water charging, together with other accompanying factors on natural ecosystems [11].

Water quality for specific use is determined using a series of indicators according to its composition, properties and concentration of matter in water. Quality is determined using a range of indicators than can be categorised as physical, chemical or biological indicators. Chemical indicators represent particularly harmful additives to water, that due to their composition, characteristics and concentration are detrimental not only for the life and health of humans, plants and animals, but also have a negative impact on the aquatic system as a whole. Chemical indicators can be categorised as inorganic and organic. Ecologically important compounds are heavy metals, which can be present in trace amounts (cadmium and lead) in natural waters, and are potentially harmful for plants, animals, and humans [8]. Significant side effect of climate changes can be the changes in the level and quality of surface waters [12], as well as changes in quality and quantity of ground water [13].

The objective of this study was to analyse the trends of specific water forms and certain climate elements and their relationships in the hydrological cycle, as well as the pollution of precipitation and ground water.

\section{MATERIAL AND METHODS}

The study was conducted in the Međustrugovi forest unit, Stara Gradiška forestry district (Figure 1). This is a lowland area with a moderately warm climate. The mean annual air temperature for this area is $10.9^{\circ} \mathrm{C}$, and the average annual precipitation is $782 \mathrm{~mm}$ (Nova Gradiška weather station, period of 1981-2012). The geological substrate of this forestry unit is redeposited marsh loess, covered by a mineral marsh soil with poor to neutral acidity. For the analysis of hydrological relationships in a lowland forest habitat, data on climatic elements and indices from Nova Gradiška weather station, water levels $(\mathrm{cm})$ of the Sava River, and data on depths of ground water $(\mathrm{cm})$ from the Međustrugovi piezometer station were used. The analysed climatic elements were mean annual precipitation $(\mathrm{mm})$ and relative air moisture (\%). The climate indices used were the climate moisture deficit index (CMD; $\mathrm{mm}$ ) and the potential evapotranspiration values $(\mathrm{mm})$. The moisture deficit index represents the sum of the monthly differences between referential evaporation and precipitation [14]. Direct determination of evapotranspiration is demanding since it is difficult to achieve the natural condition, and therefore indirect methods are used, including data on a greater or lesser number of measured climate element values [8]. Potential evapotranspiration was calculated indirectly according to [15]. Data on climate elements and indices were collected for the period of 1901-2012.

For the analysis of water levels in the Sava River, data on the maximum, mean and minimum water levels from Stara Gradiška measuring station in the period 1970-2012 were used. Ground water was measured in the Međustrugovi forest unit at four depths (PJ10.5 m; PJ2-1.5 m; PJ3-2.5 m and PJ4-7 m) in the period 2001-2012. A decrease or increase of climate and hydrological elements and indices was analysed using linear trend regression analysis. Precipitation was collected at a total of six sampling stations, and ground water was collected in three repetitions during March in 2015 and 2016. Water samples were collected in plastic (polypropylene) bottles $(100 \mathrm{~mL})$. The bottles had been previously submerged in diluted nitric acid $\left(\mathrm{HNO}_{3}\right.$, p.a., $\left.v / v \mathrm{10} \%\right)$, thoroughly rinsed with ultrapure water, and dried at room temperature in a pure air atmosphere. Determination of metal contents in the prepared samples was performed using inductively coupled plasma atomic emission spectroscopy (ICP-AES). Measurement quality was determined by measurements against the certified reference material for water SLRS-5 (National Research Council of Canada). The limit value of water contamination was taken from the Regulation of hazardous compounds in water [16], Ordinance on natural minerals, natural spring and table waters [17], Ordinance on health safety of drinking water [18], and Regulation of standard water quality [19].

Statistical data analysis (descriptive statistics, linear regression analysis, Spearman rank R correlation, ANOVA) were performed using the statistical program Statistica 7.1 [20].

\section{RESULTS}

The mean annual precipitation in the study area was $772.44 \mathrm{~mm}$. The total potential evapotranspiration was $836.77 \mathrm{~mm}$, and was higher than the total annual amount of precipitation (Table 1).

According to the results shown in Table 2, only the trend of potential evapotranspiration was positive and statistically 


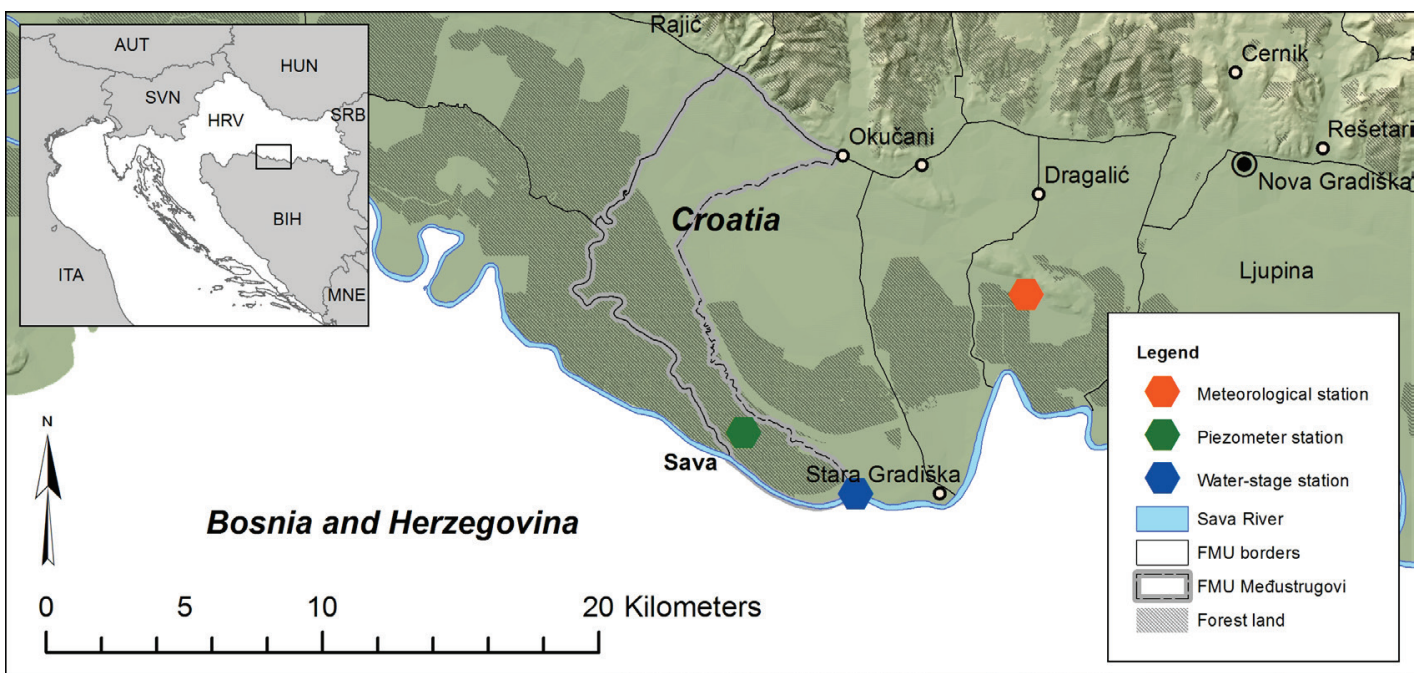

FIGURE 1. The study area

significant. The trends of annual and summer amounts of precipitation were not statistically significant.

The highest maximum water level of the Sava River was $906.00 \mathrm{~cm}$, and the minimum $106.00 \mathrm{~cm}$. The mean water level was $249.15 \mathrm{~cm}$ (Table 3).

Linear trends of maximum, mean and minimum water levels of the Sava River in the study area were negatively and statistically significant (Table 4).

The minimum ground water depth in the piezometer was $56.87 \mathrm{~cm}$, and the maximum depth was $235.73 \mathrm{~cm}$. The mean ground water depths in the piezometer ranged from $78.15 \mathrm{~cm}$ to $169.16 \mathrm{~cm}$ (Table 5).
Linear trends and the significance of trends of mean ground water depth for each piezometer were positive, though only column no. 4 showed a statistically positive trend (Table 6).

Table 7 shows the correlation of various forms of water in a lowland forest ecosystem. The strongest statistically significant correlation coefficient was found between ground water depths in piezometers no. 3 and $4\left(0.98^{*}\right)$ and the lowest statistically significant correlation coefficient was found between precipitation and ground water depth in piezometer no. $4\left(0.66^{*}\right)$.

TABLE 1. Descriptive statistics of climate elements and indices from Nova Gradiška weather station.

\begin{tabular}{lcccc}
\hline \multicolumn{1}{c}{ Climate element / index } & Average & Minimum & Maximum & Std. Dev. \\
\hline Precipitation $(\mathrm{mm})$ & 772.44 & 571.00 & 1105.00 & 108.81 \\
PET $(\mathrm{mm})$ & 836.77 & 749.00 & 906.00 & 29.22 \\
CMD (mm) & 290.45 & 115.00 & 566.00 & 92.01 \\
\hline
\end{tabular}

PET - Potential evapotranspiration: CMD - climate moisture deficit index

TABLE 2. Linear trends and the significance of trends for precipitation, air humidity, evaporation (PET) and moisture deficit (CMD).

\begin{tabular}{lccccc}
\hline Climate element / index & Linear trend & Beta & B & t & p-level \\
\hline Annual precipitation $(\mathrm{mm})$ & $\mathrm{Y}=0.121 \mathrm{x}+765.7$ & 0.0352 & 0.1213 & 0.3649 & 0.7159 \\
Relative air humidity (\%) & $\mathrm{Y}=-0.166 \mathrm{x}+74.72$ & -0.1971 & -0.1667 & -0.5319 & 0.6111 \\
PET (mm) & $\mathrm{Y}=0.294 \mathrm{x}+820.5$ & 0.3184 & 0.2943 & 3.4739 & $0.0007 *$ \\
$\mathrm{CMD}(\mathrm{mm})$ & $\mathrm{Y}=0.124 \mathrm{x}+283.6$ & 0.0427 & 0.1243 & 0.4420 & 0.6594 \\
\hline
\end{tabular}

* significant at $\mathrm{p}<0.05$ 
TABLE 3. Descriptive statistics of the Sava River water levels.

\begin{tabular}{ccccc}
\hline Variable & Average & Minimum & Maximum & Std. Dev. \\
\hline Maximum $(\mathrm{cm})$ & 698.27 & 517.00 & 906.00 & 87.24 \\
Average $(\mathrm{cm})$ & 249.15 & 58.00 & 384.00 & 82.03 \\
Minimum $(\mathrm{cm})$ & -22.21 & -106.00 & 58.00 & 48.84 \\
\hline
\end{tabular}

TABLE 4. Linear trends and significant trends of maximum, mean and minimum water levels of the Sava River.

\begin{tabular}{lccccc}
\multicolumn{1}{c}{ Water level } & Linear trend & Beta & B & t & p-level \\
\hline Maximum & $\mathrm{Y}=-6.270 \mathrm{x}+756.2$ & -0.4262 & -2.655 & -2.6235 & $0.0134^{*}$ \\
Average & $\mathrm{Y}=-5.014 \mathrm{x}+274.8$ & -0.5951 & -3.486 & -4.1226 & $0.0003^{*}$ \\
Minimum & $\mathrm{Y}=-4.341 \mathrm{x}+2.883$ & -0.8374 & -2.921 & -8.5292 & $0.0000^{*}$ \\
\hline
\end{tabular}

* significant at $\mathrm{p}<0.05$

TABLE 5. Descriptive statistics of ground water depths, measured by piezometer.

\begin{tabular}{ccccc}
\hline Piezometer & Average & Minimum & Maximum & Std. Dev. \\
\hline PJ 1 (cm) & 78.15 & 56.87 & 91.95 & 11.53 \\
PJ 2 (cm) & 145.53 & 127.03 & 169.88 & 14.52 \\
PJ 3 (cm) & 169.16 & 126.60 & 212.32 & 30.53 \\
PJ 4 (cm) & 168.65 & 125.35 & 235.73 & 36.95 \\
\hline
\end{tabular}

TABLE 6. Linear trends and significance of trends of mean ground water depth for piezometer at the Međustrugovi forest unit.

\begin{tabular}{ccccccc}
\hline Piezometer & Linear trend & Beta & B & t & p-level \\
\hline PJ 1 & $\mathrm{Y}=1.048 \mathrm{x}+71.88$ & 0.3395 & 1.05 & 1.1972 & 0.2564 \\
PJ 2 & $\mathrm{Y}=1.609 \mathrm{x}+136.8$ & 0.2964 & 1.61 & 1.0291 & 0.3255 \\
PJ 3 & $\mathrm{Y}=4.951 \mathrm{x}+144.6$ & 0.5001 & 4.95 & 1.9154 & 0.0818 \\
PJ 4 & $\mathrm{Y}=7.577 \mathrm{x}+131.3$ & 0.5880 & 7.60 & 2.4109 & $0.0346 *$ \\
\hline
\end{tabular}

* significant at $\mathrm{p}<0.05$

The strongest statistically significant negative correlation was between the climate moisture deficit index and minimum ground water levels $\left(-0.96^{*}\right)$, while the lowest negative correlation was between precipitation and climate moisture deficit index $\left(-0.68^{*}\right)$ (Table 7$)$.

The metal concentrations in precipitation and flood waters during 2015 and 2016 were lower than the limit values. There was a significantly higher content of aluminium, cadmium, copper and zinc in precipitation than in flood waters. The content of iron was significantly higher in flood waters than in precipitation (Figure 2).

\section{DISCUSSION}

In the study area, of all the analysed climatic elements and indices, only the potential evapotranspiration trend showed a statistically significant increase. Global trends of warming can have effect on evapotranspiration which has direct effect on the sustainability of surface and ground water [21]. Annual quantities of precipitation showed a positive trend, though this was not statistically significant. Atmosphere capacity for taking and holding water exponentially increases with temperature, and due to that the increase of precipitation in forecasted. 
TABLE 7. Spearman's R correlation of hydrological factors

\begin{tabular}{|c|c|c|c|c|c|c|c|c|c|c|c|}
\hline Variable & $\mathbf{P}$ & RH & PET & CMD & Max. V & Ave. V & Min. V & PJ 1 & PJ 2 & PJ 3 & PJ 4 \\
\hline $\mathbf{P}$ & 1.00 & - & - & - & - & - & - & - & - & - & - \\
\hline RH & 0.53 & 1.00 & - & - & - & - & - & - & - & - & - \\
\hline PET & -0.41 & $-0.88^{*}$ & 1.00 & - & - & - & - & - & - & - & - \\
\hline CMD & $-0.68^{*}$ & $-0.79 *$ & 0.63 & 1.00 & - & - & - & - & - & - & - \\
\hline Max. V & $0.66^{*}$ & 0.62 & -0.65 & $-0.85^{*}$ & 1.00 & - & - & - & - & - & - \\
\hline Sred. V & $0.71^{*}$ & $0.85 *$ & $-0.78 *$ & $-0.90 *$ & $0.83^{*}$ & 1.00 & - & - & - & - & - \\
\hline Min. V & 0.63 & $0.72 *$ & 0.61 & $-0.96 *$ & $0.88^{*}$ & $0.88^{*}$ & 1.00 & - & - & - & - \\
\hline PJ 1 & 0.56 & -0.15 & 0.08 & 0.11 & -0.25 & -0.13 & -0.31 & 1.00 & - & - & - \\
\hline PJ 2 & 0.60 & 0.40 & $-0.65^{*}$ & -0.40 & 0.50 & 0.58 & 0.40 & $0.68^{*}$ & 1.00 & - & - \\
\hline PJ 3 & $0.68^{*}$ & 0.80 & $-0.81 *$ & -0.48 & 0.33 & 0.60 & 0.46 & 0.40 & $0.83^{*}$ & 1.00 & - \\
\hline PJ 4 & $0.66^{*}$ & -0.73 & -0.40 & -0.80 & -0.48 & $0.71 *$ & $0.76^{*}$ & 0.35 & $0.78^{*}$ & $0.98^{*}$ & 1.00 \\
\hline
\end{tabular}

* significant at $\mathrm{p}<0.05$

$\mathrm{P}$ - precipitation, $\mathrm{RH}$ - relative air humidity, PET - potential evapotranspiration, CMD - climate moisture deficit, Max. V - maximum water level, Ave. V - average water level, Min. V - minimum water level, PJ - piezometer

However, changes in spatial and seasonal amount of precipitation will occur [22]. This increase in the quantity of precipitation in the study area does not necessary mean greater quantities of available water for vegetation. According to Ondrašek et al. [10], the water balance in an ecosystem can be described by the equation: water balance = input (precipitation, surface and ground flow) - output (evaporation, transpiration, runoff, infiltration).

Changes in trends of any of the components of this equation will certain impact the water balance in the ecosystem. Significant increases in evapotranspiration as an output variable will negatively impact the water balance in the ecosystem. A significant increase in the amount of evapotranspiration is primarily due to strong increases in air temperature [23].

The increase of precipitation, temperature and evapotranspiration could have different effect on different water-holding layers, i.e. aquifers [11].

In lowland forests, a particular problem is the disturbance of the regime of surface and ground waters caused by agricultural amelioration and other water regulation works for the purpose of flood control. Water regulation works in lowland forest areas have changed the dynamics of the flood and ground waters, and recent climate changes have altered river water levels. Ground water is not a static category and instead shows a seasonal tendency associated with the regime of the catchment area. In the winter/spring period, the ground water levels reach the soil surface in most of the lowland forests, connecting with flood waters in certain areas [24]. A higher number of dry days were recorded in the Međustrugovi forest unit in the period from 2001 to 2012, resulting in a drop in ground water levels in certain piezometer columns [25]. In this area, the water levels in the Sava River also affect ground water levels, which also decreased during the study.

In the hydrological cycle, water is found in various forms, from liquid to gaseous. Water also passes through various spheres, from the atmosphere through the ground surface to the underground. This study established significant correlations between atmospheric, surface and ground waters in the lowland forest ecosystem. A significant and negative correlation was found between potential evapotranspiration and the level of ground water at depths of $1.5 \mathrm{~m}$ and $2.5 \mathrm{~m}$. An increase in the amount of potential evapotranspiration increases water consumption and reduces soil moisture, thus reducing ground water stocks in lowland forests. These results confirm the results of comparative water balance study in Hungary [26]. They stated that during periods of drought, the share of water consumption from ground waters in English oak forests was up to $90 \%$ of the amount of transpiration, while during wet weather, water consumption from ground water was significantly lower.

According to Ondrašek et al. [10], in the moderate climate belt, where the average annual precipitation ranges from 500 to $1500 \mathrm{~mm}$, the output variables of the hydrological cycle (evapotranspiration, infiltration and runoff) are equally represented, each accounting for approximately $33 \%$ of the quantity of precipitation. It can be assumed that with significant increases in the amounts of potential evapotranspiration, this percentage ratio will change. According to the results in Table 7, the quantity of precipitation significantly affects water levels in the Sava River. Also, precipitation significantly increases ground water levels. The results of this study in the Posavina region (Međustrugovi forest unit) confirmed an earlier study in the 


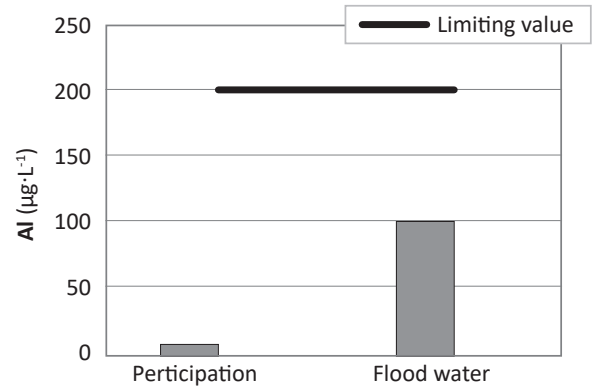

Significant, $p=0.009$

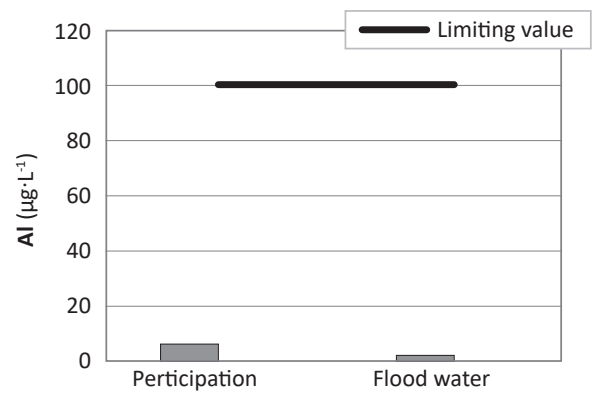

Significant, $p=0.008$

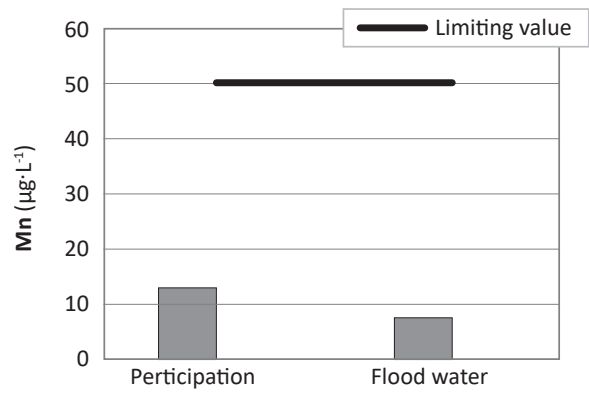

Significant, $p=0.754$

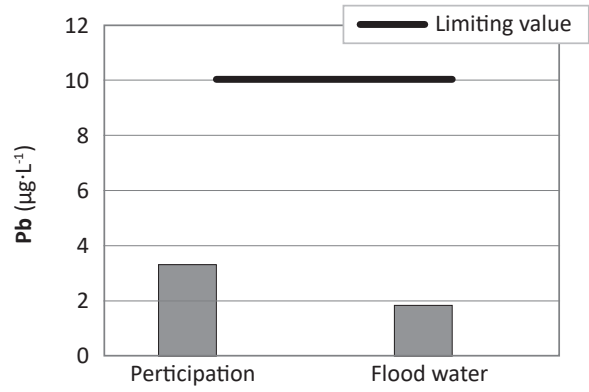

Significant, $p=0.577$

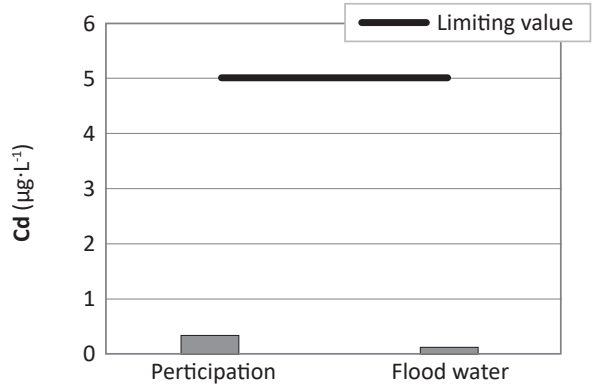

Significant, $p=0.005$

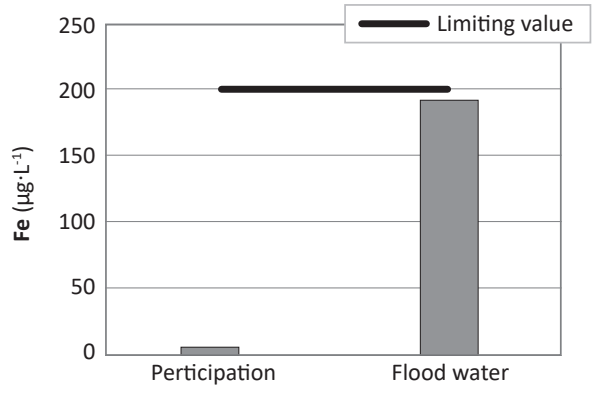

Significant, $p=0.009$

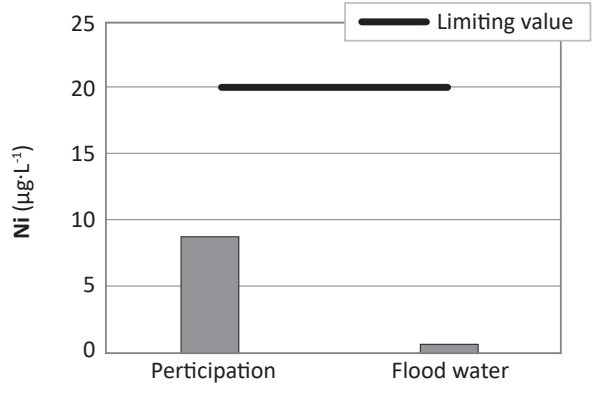

Significant, $p=0.009$

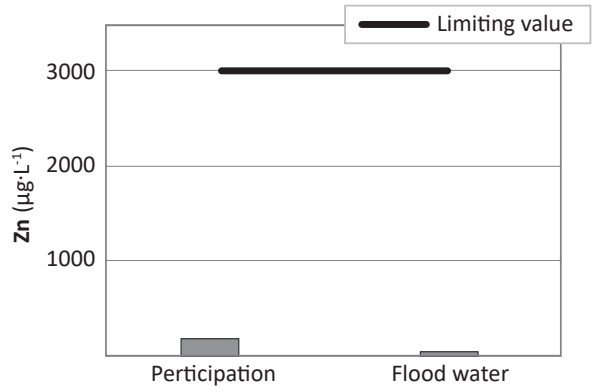

Significant, $p=0.009$

FIGURE 2. Metal content in precipitation and floods 
Podravina region in the Repaš forest unit on the connection of surface water courses with ground water levels [3].

However, the trends of maximum, mean and minimum water levels of the Sava River were significantly reduced in the study area, meaning that the ground levels will also be reduced, while with increased amounts of potential evapotranspiration, the amount of water in the lowland forest ecosystem will decline. According to Ceglar and Rakovec [27], in the catchment basin of the Sava River, forecasts for the $21^{\text {st }}$ century include an increase in air temperatures in all seasons of the year, and significantly decreased quantities of precipitation in the summer period, while there will be less reductions of precipitation in spring and autumn. The decrease of precipitations in summer months will result also in the decrease of Sava river water level, and the decrease of ground water level, since they are correlated. Surely, forecasted decrease of precipitations in summer months will cause changes in the precipitation regime in lowland forest areas.

Knowing water quality enables an understanding of its origin, the possibilities for use of such water, the presence of pollutants, and the possibility of removing those pollutants [28]. From the chemical indicators monitored in precipitation and ground water, all analysed metals had concentrations under the limit values (Figure 2). This supports a previous studies $[29,30]$ that reported that water pollution of the Sava River with elements such as $\mathrm{Cu}, \mathrm{Ni}, \mathrm{Zn}$ and $\mathrm{Pb}$ was low. Iron (Fe) is present in nature as a result of pipe corrosion, the rinsing of acidic ores, and industrial waste waters containing iron. It is found completely dissolved in water, or in colloid form. Iron concentrations in this study approached the limit values of $200 \mu \mathrm{g} \cdot \mathrm{L}^{-1}$ [18]. Higher concentrations of aluminium and iron can be explained by the stagnation of flood water. The atmosphere also influences the pollution of precipitation and ground water, and is an important medium for pollution transport. Pollutants are deposited from the air onto soil as parts of aerosols. Some metals settle due to the activity of gravity, and are then rinsed from vegetation into the soil and further into the ground waters, lakes, rivers and seas [24]. Furthermore, the activity of microorganisms in water and the anthropogenic effects in the environment post a significant threat for watercourse pollution [8]. The established differences in the concentrations of heavy metals in precipitation and flood waters are certain due to the composition of water, determined by a series of processes that unfold in the environment, primarily physical, chemical and biological processes.

\section{CONCLUSIONS}

The trends of the potential levels of evapotranspiration were positive and statistically significant. The precipitation trends and moisture deficit index were also positive, but not statistically significant. The maximum, mean and minimum water levels of the Sava River showed a statistically significant reduction in the study area. Ground water depths increased in all piezometer columns. This trend, however, was statistically significant only for column no. 4. This study found statistically significant correlations between atmospheric, surface waters and ground waters in lowland forest ecosystems. Increased precipitation significantly increased the maximum and mean water levels of the Sava River. Additionally, an increase in precipitation levels significantly decreased the depths of ground water, especially in columns at greater depths. An increase in relative air moisture reduced the moisture deficit and the amount of potential evapotranspiration. With increasing amounts of potential evapotranspiration, forest trees increase their use of water from the ground water. At higher water levels of the Sava River, the moisture deficit index in the ecosystem was significantly reduced. With an increase in the mean and minimum water levels of the Sava River, the level of ground waters increased at greater depths. Increased concentrations of $\mathrm{Cd}, \mathrm{Cu}, \mathrm{Mn}, \mathrm{Ni}, \mathrm{Pb}, \mathrm{Zn}$ were measured in precipitation. Flood water contained increased concentrations of $\mathrm{Al}$ and Fe. The pollution of precipitation and flood water was beneath the limit values.

\section{REFERENCES}

1. NANDARGI S, PATEKAR TA, MULYE SS 2014 Rainfall and Groundwater Level Variation in Pune District, India. Studies in Atmospheric Science 1: 24-40

2. PRPIĆ B, VRATARIĆ P, SELETKOVIĆ Z 2005 Utjecaj snage rijeke na postanak i opstanak poplavnih šuma. In: Vukelić J, Matić $\mathrm{S}$, Gračanin J (eds) Floodplain forests in Croatia. Academy of Forestry Sciences, Zagreb, Croatia, pp 168-173

3. PRPIĆ B 1985 The Influence of the Water Suice Đurđevac on the Repaš Forest (in Croatian with English summary). Sumar list 109 (11-12): 539-551

4. RAUŠ Đ 1990 The Succession of Forest Vegetation in the Spačva Basin in the Period from 1970 to 1989 (in Croatian with English summary). Sumar list 114 (9-10): 341-356

5. RAUŠ Đ, VUKELIĆ J 1989 Rezultati komparativnih istraživanja šumske vegetacije na području sušenja hrasta lužnjaka. Glas šum pokuse 25: 53-56

6. MAYER D 1995 Scope and meaning of the ground and surface water monitoring for the lowland forests in Croatia (in Croatian with English summary). Sumar list 119 (11-12): 19-32
7. PRPIĆ B 2003 The Effects of Technical Operations in the Area of Lowland Forests (in Croatian with English summary). Sumar list 127 (5-6): 230-235

8. ŠIMUNIĆ I 2013 Uređenje voda. Hrvatska Sveučilišna Naklada, University of Zagreb, Croatia, $260 \mathrm{p}$

9. GEREŠ D 2004 Circulation of water in the terrestrial system (in Croatian with English summary). Građevinar 56 (6): 355-365

10. ONDRAŠEK G, PETOŠIĆ D, TOMIĆ F, MUSTAĆ I, FILIPOVIĆ V, PETEK M, LAZAREVIĆ B, BUBALO M 2015 Voda u agroekosustavima. University of Zagreb, Faculty of Forestry, Zagreb, Croatia, $343 \mathrm{p}$

11. GREEN RT, TANIGUCHI M, KOOI H, GURDAK JJ, ALLEN DM, HISCOOCK KM, TREIDEL H, AURELI A 2011 Beneath the surface of global change: Impacts of climate change on groundwater. J Hydrol 405 (3-4): 532-560. DOI: https://doi. org/10.1016/j.jhydrol.2011.05.002

12. LEITH RMM, WHITFIELD PH 1998 Evidence of climate change effects on the hydrology of streams in south-central B.C. Can Water Resour J 23 (3): 219-230. DOI: https://doi.org/10.4296/ cwri2303219 
13. BEAR J, CHENG HD 1999 SEAWATER Intrusion in Coastal Aquifers - Concepts, Methods and Practices. Kluwer Academic Publisher, Dordrecht, Boston, London, 625 p. DOI: https://doi. org/10.1007/978-94-017-2969-7

14. HARGREAVES GH, SAMANI ZA 1985 Reference crop evapotranspiration from temperature. App Eng Agric 1 (2): 9699. DOI: https://doi.org/10.13031/2013.26773

15. THORNTHWAITE CW 1948 An Approach Toward a Rational Classification of Climate. Georg Rew 38: 55-94

16. THE GOVERNMENT OF THE REPUBLIC OF CROATIA 1998 Regulation of hazardous compounds in water. Official Gazette 78/98, Zagreb, Croatia

17. THE MINISTRY OF AGRICULTURE, FISHERIES AND RURAL DEVELOPMENT Ordinance on natural minerals, natural spring and table waters. Official Gazette 02/05, Zagreb, Croatia. URL: http://www.mvep.hr/zakoni/pdf/515.pdf (9 January 2017)

18. THE MINISTRY OF HEALTH AND SOCIAL WELFARE 2008 Ordinance on health safety of drinking water. Official Gazette $47 / 08$

19. THE GOVERNMENT OF THE REPUBLIC OF CROATIA 2013 Regulation of standard water quality. Official Gazette 73/13

20. HILL T, LEWICKI P 2007 STATISTICS: Methods and Applications. StatSoft, Inc., Tulsa, OK, USA, $800 \mathrm{p}$

21. BARNETT TP, PIERCE DW, HIDALGO HG, BONFILS C, SANTER BD, DAS T, BALA G, WOOD AW, NOZAWA T, MIRIN AA, CAYAN DR, DETTINGER MD 2008 Humaninduced changes in the hydrology of western United States. Science 319 (5866): 1080-1083. DOI: https://doi.org/10.1126/science.1152538

22. IPCC 2007 Climate change 2007 the physical science basis. Contribution of working I to the fourth assessment report of the intergovernmental panel on climate change. In: Solomon S, Qin D, Manning M, Chen Z, Marquis M, Averyt KB, Tignor M, Mille HL (eds), Cambridge University Press, Cambridge, UK and New York, USA, $996 \mathrm{p}$
23. UGARKOVIĆ D, TIKVIĆ I, MIKAC S, VUČETIĆ M, KUZMANIĆ S 2015 Climate changes and theirs influence on ecological niche of pedunculate oak in the area of lowland forest ecosystems of the Republic Croatia (Klimatske promjene i njihov utjecaj na ekološku nišu hrasta lužnjaka na području nizinskih šumskih ekosustava Republike Hrvatske). In: Matić S, Tomić F, Anić I (eds) Proizvodnja hrane i šumarstvo - temelj razvoja istočne Hrvatske. Croatian Academy of Science and Arts, Zagreb, Croatia, pp 237-253

24. VRBEK B, PILAŠ I, POTOČIĆ N, SELETKOVIĆ I 2006 The Research of Groundwater Table Levels, Input of Heavy Metals and Crown Condition in Forest Ecosystems of Croatia. Radovi (special issue) 9: 159-180

25. BALTA D 2015 Hydrological relations of water in the ecosystem and quality of rainwater and floodwaters (in Croatian with English summary). Thesis, University of Zagreb, Faculty of Forestry, Zagreb, Croatia, $37 \mathrm{p}$

26. MÓRICZ N, MÁTYÁS C, BERKI I, RASZTOVITS E, VEKERDY Z, GRIBOVSZKI Z, 2012 Comparative water balance study of forest and fallow plots. iForest 5: 188-196. DOI: https://doi. org/10.3832/ifor0624-005

27. CEgLAR A, RAKOVEC J 2015 Climate Projections for the Sava River Basin. In: Milačić R, Ščančar J, Paunović M (eds) The Sava River. Springer Berlin Heidelberg, Germany, pp 53-74. DOI: https://doi.org/10.1007/978-3-662-44034-6 3

28. LEVAČIĆ E 1997 Osnove geokemije vode. Sveučilište u Zagrebu, Geotehnički fakultet u Varaždinu, Zagreb, Croatia, pp 183-211

29. OGRINC N, KANDUČ T, KOCMAN D 2015 Integrated Approach to the Evaluation of Chemical Dynamics and Anthropogenic Pollution Sources in the Sava River Basin. In: Milačić $R$, Ščančar J, Paunović M (eds) The Sava River. Springer Berlin Heidelberg, Germany, pp 75-94. DOI: https://doi.org/10.1007/978-3-66244034-6 4

30. DRAGUN Z, FILIPOVIĆ MARIJIĆ V, VUKOVIĆ M, RASPOR B 2015 Metal Bioavailability in the Sava River Water. In: Milačić R, Ščančar J, Paunović M (eds) The Sava River. Springer Berlin Heidelberg, Germany, pp 123-155. DOI: https://doi. org/10.1007/978-3-662-44034-6 6 